\title{
DVIEJŲ MĖNESIŲ SKIRTINGOS TRUKMĖS AEROBINIŲ PRATYBŲ POVEIKIS MERGINŲ ANAEROBINẼS APYKAITOS SLENKSČIAMS
}

\author{
Asta Mockiené $\dot{1}^{1,2}$, Arvydas Stasiulis $^{1}$, Pranas Mockus $^{1}$ \\ Lietuvos kūno kultūros akademija ${ }^{1}$, Vytauto Didžiojo universitetas ${ }^{2}$, Kaunas, Lietuva
}

\begin{abstract}
Asta Mockienè. Lietuvos kūno kultūros akademijos biomedicinos mokslų krypties doktorantė. Vytauto Didžiojo universiteto Sporto centro
\end{abstract} lektorè. Mokslinių tyrimų kryptis — aerobinio pajègumo fiziologija.

\section{SANTRAUKA}

Tyrimo tikslas - palyginti 40-ies ir 60-ies minučiu trukmès laktato slenksčio intensyvumu atliekamu pratybu poveiki merginu anaerobinès apykaitos slenksčiams.

Tirtos 34 sveikos, anksčiau nesportavusios, nerūkančios merginos. Jos buvo suskirstytos i tris grupes: 2 eksperimen-

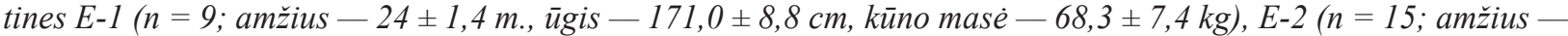

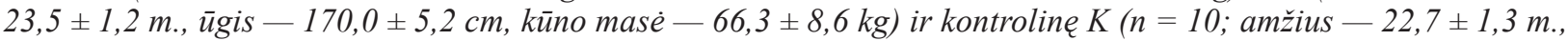
$\bar{u}$ gis - 169,0 \pm 4,4 cm, kūno masé - 65,8 \pm 8,9 kg). Aštuonias savaites E-1 ir E-2 grupés tiriamosios tris kartus per savaitę suko veloergometro pedalus laktato slenksčio (LaS) intensyvumu. E-1 grupés tiriamuju vieneriu pratybu trukmé - 40, E-2 - 60 minučiu. K grupés merginos fizinio aktyvumo pratybu neturéjo.

LaS ir laktato kaupimosi slenksčius (LKS) nustatème taikydami veloergometrini kartotinio nuosekliai didinamo krūvio testa (KDK). LaS ir LKS identifikavome pagal laktato (La) koncentracijos kraujyje priklausomuma nuo krūvio galingumo taikant tiesinès regresijos analizę. Visu grupiu tiriamuju minèti rodikliai buvo matuojami du kartus: prieš 8 savaičiu eksperimentini laikotarpi ir po jo.

Tyrimo rezultatai parodè, kad dèl aerobiniu pratybu 40 min dirbusioje E-1 grupèje statistiškai reikšmingu AAS (anaerobinès apykaitos slenksčiu) pokyčiu nenustatyta. E-2 grupejje reikšmingai padidèjo LaS $(p=0,021), \operatorname{LKS}(p=0,013)$ ir ŠSD ties LKS (p=0,039). K grupeje tirti rodikliai reikšmingai nepakito.

Atlikus tyrima galima daryti ǐsvadq: 60 min trukmés aerobinés pratybos, atliekamos du mènesius triskart per savaitę laktato slenksčio intensyvumu, reikšmingai padidino merginu AAS, kai tuo tarpu 40 min trukmés pratybos reikšmingo poveikio neturejjo.

Raktažodžiai: laktatas, anaerobinès apykaitos slenksčiai, aerobiniu pratybu trukmè, veloergometrija.

\section{IVADAS}

$\mathrm{V}$ ienas iš žmogaus aerobini pajègumą (AP) apibūdinančiu rodiklių yra anaerobinès apykaitos slenksčiai, kurie didinamo krūvio metu rodo perèjimą nuo aerobinès ATF resintezès prie anaerobinès (Wasserman et al., 1973; Skinner, McLellan, 1980). Dažniausiai išskiriami du ši perejjimą apibūdinantys rodikliai - laktato slenkstis (LaS) ir laktato kaupimosi slenkstis
(LKS) (Cabrera, Chizeck, 1996). Žinant šiuos rodiklius galima ivvertinti AP ir skirti sveikatą stiprinančiu pratybu intensyvumą (American College of Sports Medicine, 2006). LaS kitimas geriausiai rodo laktato apykaitos pokyčius ir yra aerobinę ištvermę lavinančių asmenų treniruotès poveikio rodiklis, pagal kuri galima prognozuoti varžybų rezultatus (Weltman, 1995). 
AP lavinimas sveikatos požiūriu yra naudingiausias, nes sukelia kompleksinius ilgalaikius fiziologinius širdies ir kraujagyslių, kvèpavimo ir raumenų sistemos atsakus (Londeree et al., 1997; Meyer et al., 2007). Aerobiniu pratybų paveikumas priklauso nuo jų intensyvumo, dažnumo, trukmès ir pradinio treniruotumo ( $\mathrm{McNicol}$ et al., 2009). Atlikta nemažai tyrimų, kurių metu nustatyta, kaip fizinio krūvio intensyvumas veikia anaerobinès apykaitos slenksčius (AAS) (Stasiulis et al., 2000; Meyer et al., 2007; McNicol et al., 2009). Norint paveikti AP ir sveikatą, dažniausiai rekomenduojama ištisinių aerobinių pratybų trukmè — nuo 20 iki 60 minučiu (Pollock, Wenger, 1998; Kesaniemi et al., 2001). Palyginti nedaug žinoma apie skirtingos trukmès pratybų poveiki dirbant tuo pačiu intensyvumu. Nustatyta, kad 45 minučiu trukmès pratybos labiau padidina moterų maksimaluji deguonies suvartojimą $\left(\dot{\mathrm{VO}}_{2 \max }\right)$ negu reguliarios 30 minučiu pratybos, kai jų intensyvumas $50 \% \quad \dot{\mathrm{V}} \mathrm{O}_{2 \max }$ (Dalleck et al., 2009). Nèra duomenų apie skirtingos trukmès vidutinio intensyvumo aerobiniu pratybų poveiki jaunu merginų AAS.

Tyrimo tikslas - palyginti 40 -ies ir 60 -ies minučiu trukmès laktato slenksčio intensyvumu atliekamu pratybu poveiki merginu AAS.

\section{TYRIMO ORGANIZAVIMAS IR METODIKA}

Tiriamosios. 34 sveikos, anksčiau nesportavusios, nerūkančios studentès buvo suskirstytos $\mathfrak{i}$ tris grupes: 2 eksperimentines (E-1, E-2) ir kontrolinę $(\mathrm{K})$. Tiriamujų rodikliai pateikti 1 lentelèje.

Tyrimui atlikti gautas Lietuvos bioetikos komiteto leidimas (2006 06 29, Nr. BE-2-38).

Tyrimo organizavimas. Aštuonias savaites E-1 ir E-2 grupių tiriamosios tris kartus per savaitę suko veloergometro pedalus LaS intensyvumu. E-1 grupès tiriamujų vieneriu pratybų trukmè 40 , E-2 - 60 minučių. $\mathrm{K}$ grupès merginos fizinio aktyvumo pratybų neturejo. Visų grupių tiriamuju AAS buvo matuojami du kartus: prieš aštuoniu savaičiu eksperimentini laikotarpi ir po jo.
Metodai. Norint nustatyti LaS, LKS, La koncentraciją kraujyje ties LaS ir LKS, ŠSD pasiekus LaS ir LKS, tiriamosios „Monark 834E“ veloergometru atliko kartotinio nuosekliai didinamo krūvio testa. Mynimo dažnis - $70 \mathrm{k}$. / min. Pirmo krūvio trukmè -4 min, vèlesniu -3 min. Po kiekvieno iš jų buvo daroma pasyvaus sèdèjimo 4 min poilsio pertrauka. Pirmo krūvio dydis $-50 \mathrm{~W}$. Jis buvo didinamas po $25 \mathrm{~W}$, kol La koncentracija kraujyje peržengdavo $4 \mathrm{mmol} / 1$ ribą, o tiriamojo S̆SD viršydavo $80 \%$ maksimaliojo (apskaičiuoto pagal formulę: 220 - tiriamojo asmens amžius). Trečią poilsio minutę iš rankos piršto, prieš tai jo odą dezinfekavus, buvo imami 0,1 ml kapiliarinio kraujo mèginiai. La koncentracija nustatyta „Eksan-G“ analizatoriumi (Kulis et al., 1988), kuriame imontuota membrana su laktato oksidazès fermentu, galinčiu nustatyti laktato koncentracija kraujyje nuo 0,8 iki $25,0 \mathrm{mmol} / 1$. Viso tyrimo metu $5 \mathrm{~s}$ intervalais ŠSD buvo registruojamas „Polar S810“ pulso matuokliu (Suomija) ir toliau analizuojamas taikant „Polar Precision Performance“ programą.

AAS buvo nustatomi analizuojant La koncentracijos kraujyje priklausomumą nuo krūvio galingumo iš kreivès lūžio tašku, taikant tiesinès regresijos analizę. LaS nustatytas pagal laktato koncentracijos didejimo pradžią ir LKS - staigaus laktato koncentracijos kraujyje didejjimo pradžią (Tanaka, 1990; Cabrera, Chizeck, 1996).

Matematinė statistika. Tyrimo duomenims apdoroti buvo taikyti šie matematinès statistikos metodai:

- Aritmetinio vidurkio ir standartinio nuokrypio skaičiavimai.

- Duomenu ir normaliojo skirstinio atlikimui nustatyti taikytas Kolmogorovo-Smirnovo testas.

- Rodikliu pokyčiai tirtose grupėse buvo vertinami naudojant priklausomujų imčių neparametrini Vilkoksono (Wilcoxon) testą.

- Statistinių hipotezių patikimumui izvertinti pasirinktas reikšmingumo lygmuo, kai $\mathrm{p}<0,05$. Duomenų skaičiavimams atlikti naudotos kompiuterinès programos „Polar Precision Performance“, „Microsoft Excel“, „Origin“, „STATISTICA for Windows“.

\begin{tabular}{|c|c|c|c|c|c|c|}
\hline $\begin{array}{l}1 \text { lentelè. Pratybų trukmė, tiriamųjų } \\
\text { skaičius, amžius, ūgis ir kūno masè }\end{array}$ & Grupės & $\begin{array}{c}\text { Pratybų } \\
\text { trukmè, min }\end{array}$ & Imties tūris, $n$ & Amžius, m. & $\overline{\text { Ügis, }} \mathbf{m}$ & Kūno masė, kg \\
\hline \multirow{3}{*}{$\begin{array}{l}\text { Pastaba. Pateikti vidurkiai, skliauste- } \\
\text { liuose - standartiniai nuokrypiai. }\end{array}$} & E-1 & 40 & 9 & $24,0(1,4)$ & $1,71(8,8)$ & $68,3(7,4)$ \\
\hline & E-2 & 60 & 15 & $23,5(1,2)$ & $1,70(5,2)$ & $66,3(8,6)$ \\
\hline & $\mathrm{KG}$ & - & 10 & $22,7(1,3)$ & $1,69(4,4)$ & $65,8(8,9)$ \\
\hline
\end{tabular}




\section{REZULTATAI}

Analizuojami rodikliai prieš 8 savaičių pratybų programą ir po jos pateikti 2 lentelèje. Prieš reguliariu pratybų pradžią tarp tiriamu grupių reikšmingo rodikliu skirtumo nenustatyta.

E-1 grupès tiriamuju LaS (1 pav.), LKS (2 pav.), ŠSD ties LaS (3 pav.), ŠSD (4 pav.) ir La koncentracijos kraujyje pasiekus LKS (6 pav.) pokyčio rodikliai nebuvo statistiškai reikšmingi
( $p>0,05)$. E-1 grupès merginų grupèje statistiškai reikšmingai sumažejo tik La koncentracija kraujyje pasiekus LaS ( $\mathrm{p}=0,008,5$ pav.). E-2 grupeje statistiškai reikšmingai pakito šie rodikliai: LaS $(\mathrm{p}=0,021,1$ pav. $)$ ir LKS padidèjo $(\mathrm{p}=0,013$, 2 pav.), ŠSD ties LKS taip pat padidèjo ( $p=0,039$, 4 pav.). La koncentracija kraujyje ties LaS ir LKS (5 ir 6 pav.), ŠSD pasiekus LaS reikšmingai nepakito ( $p>0,05,3$ pav.). $K$ grupejje reikšmingų tirtu rodikliu pokyčių nebuvo (2 lent. ir $1-6$ pav.).

2 lentelè. Tiriamų grupių AAS rodiklių vidutinès reikšmės prieš 8 savaičių aerobines pratybas ir po jų

\begin{tabular}{|c|c|c|c|c|c|c|}
\hline Tiriamųjų grupės & \multicolumn{2}{|c|}{ E-1 (40 min) } & \multicolumn{2}{|c|}{ E-2 (60 min) } & \multicolumn{2}{|c|}{$\mathbf{K}$} \\
\hline Testavimas & $\begin{array}{c}\text { Prieš } \\
\text { eksperimentą }\end{array}$ & $\begin{array}{c}\text { Po } \\
\text { eksperimento }\end{array}$ & $\begin{array}{c}\text { Prieš } \\
\text { eksperimentą }\end{array}$ & $\begin{array}{c}\text { Po } \\
\text { eksperimento }\end{array}$ & $\begin{array}{c}\text { Prieš } \\
\text { eksperimentą }\end{array}$ & $\begin{array}{c}\text { Po } \\
\text { eksperimento }\end{array}$ \\
\hline LaS, W & $117,92(13,76)$ & $\begin{array}{c}127,9(27,78) \\
p=0,139\end{array}$ & $116,87(15,75)$ & $\begin{array}{c}127,87(23,00)^{*} \\
\mathrm{p}=0,021\end{array}$ & $102,86(17,66)$ & $\begin{array}{c}105,64(16,02) \\
p=0,26\end{array}$ \\
\hline ŠSD ties LaS, k. / min & $133,63(9,96)$ & $\begin{array}{c}135,8(9,00) \\
\mathrm{p}=0,308\end{array}$ & $146,41(9,08)$ & $\begin{array}{c}150,21(9,72) \\
p=0,198\end{array}$ & $147,44(8,11)$ & $\begin{array}{c}152,5(7,76) \\
p=0,293\end{array}$ \\
\hline $\begin{array}{l}\text { La konc. kraujyje ties } \\
\mathrm{LaS}, \mathrm{mmol} / 1\end{array}$ & $1,43(0,37)$ & $\begin{array}{c}2,19(0,25)^{*} \\
\mathrm{p}=0,008\end{array}$ & $2,03(0,59)$ & $\begin{array}{c}1,98(0,68) \\
p=0,729\end{array}$ & $2,08(0,78)$ & $\begin{array}{c}1,72(0,77) \\
p=0,514\end{array}$ \\
\hline LKS, W & $189,94(26,32)$ & $\begin{array}{c}202,2(27,39) \\
p=0,059\end{array}$ & $155,54(26,15)$ & $\begin{array}{c}179,89(34,49)^{*} \\
\mathrm{p}=0,013\end{array}$ & $161,66(30,57)$ & $\begin{array}{c}161,85(24,67) \\
p=0,858\end{array}$ \\
\hline $\begin{array}{l}\text { La konc. kraujyje ties } \\
\text { LKS, mmol / } 1\end{array}$ & $3,62(0,80)$ & $\begin{array}{l}4,15(0,72) \\
p=0,059\end{array}$ & $3,87(0,89)$ & $\begin{array}{c}4,17(0,98) \\
p=0,637\end{array}$ & $4,78(0,76)$ & $\begin{array}{l}4,52(1,16) \\
p=0,952\end{array}$ \\
\hline ŠSD ties LKS, k. / min & $165,26(6,47)$ & $\begin{array}{c}168,53(7,29) \\
p=0,092\end{array}$ & $169,73(8,54)$ & $\begin{array}{c}172,73(7,46)^{*} \\
p=0,039\end{array}$ & $167,35(7,36)$ & $\begin{array}{c}163,48(6,99) \\
p=0,05\end{array}$ \\
\hline
\end{tabular}

Pastaba. Skliausteliuose pateikti rodiklių standartiniai nuokrypiai. * — skirtumas statistiškai reikšmingas, lyginant su pirmo tyrimo rodikliais $(\mathrm{p}<0,05)$.
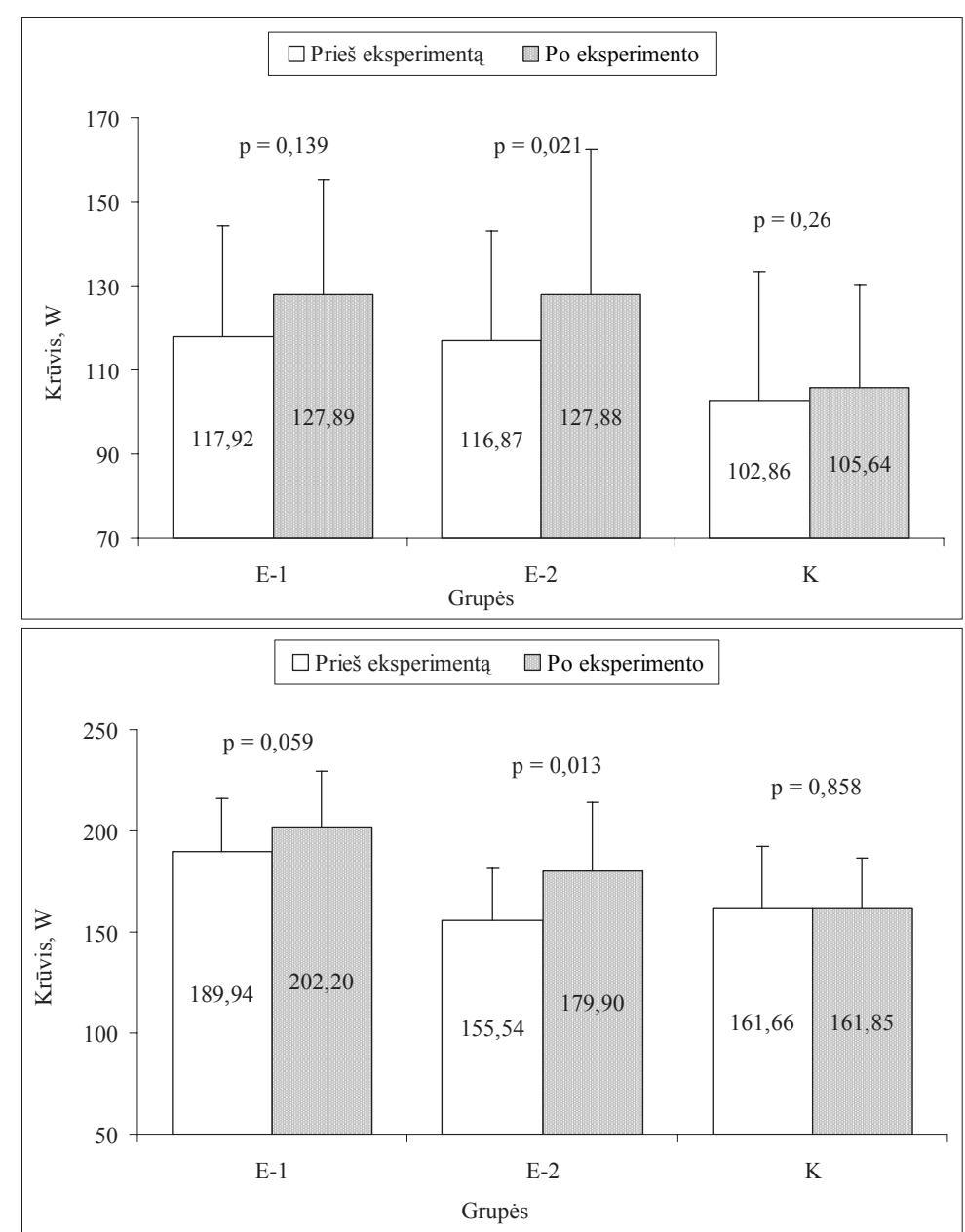

1 pav. Tiriamų grupių LaS prieš 8 savaičių aerobines pratybas ir po jụ

Pastaba. Skirtumas statistiškai reikšmingas, kai $\mathrm{p}<0,05$.

2 pav. Tiriamų grupių LKS prieš 8 savaičių aerobines pratybų ir po jų

Pastaba. Skirtumas statistiškai reikšmingas, kai $\mathrm{p}<0,05$. 
3 pav. Tiriamų grupių ŠSD ties LaS prieš 8 savaičiụ aerobines pratybas ir po jų

Pastaba. Skirtumas statistiškai reikšmingas, kai $\mathrm{p}<0,05$.

4 pav. Tiriamų grupių ŠSD ties LKS prieš $\mathbf{8}$ savaičių aerobines pratybas ir po jų

Pastaba. Skirtumas statistiškai reikšmingas, kai $\mathrm{p}<0,05$.

5 pav. Tiriamų grupių La koncentracijos kraujyje ties LaS prieš 8 savaičių aerobines pratybas ir po jų

Pastaba. Skirtumas statistiškai reikšmingas, kai $\mathrm{p}<0,05$.

\section{REZULTATŲ APTARIMAS}

Šiuo tyrimu nustatyta, kad tik 60 minučiu trukmès aerobinès pratybos, atliekamos LaS intensyvumu, reikšmingai padidino merginu AAS, kai tuo tarpu 40 minučiu pratybos statistiškai reikšmingai nepaveikè.
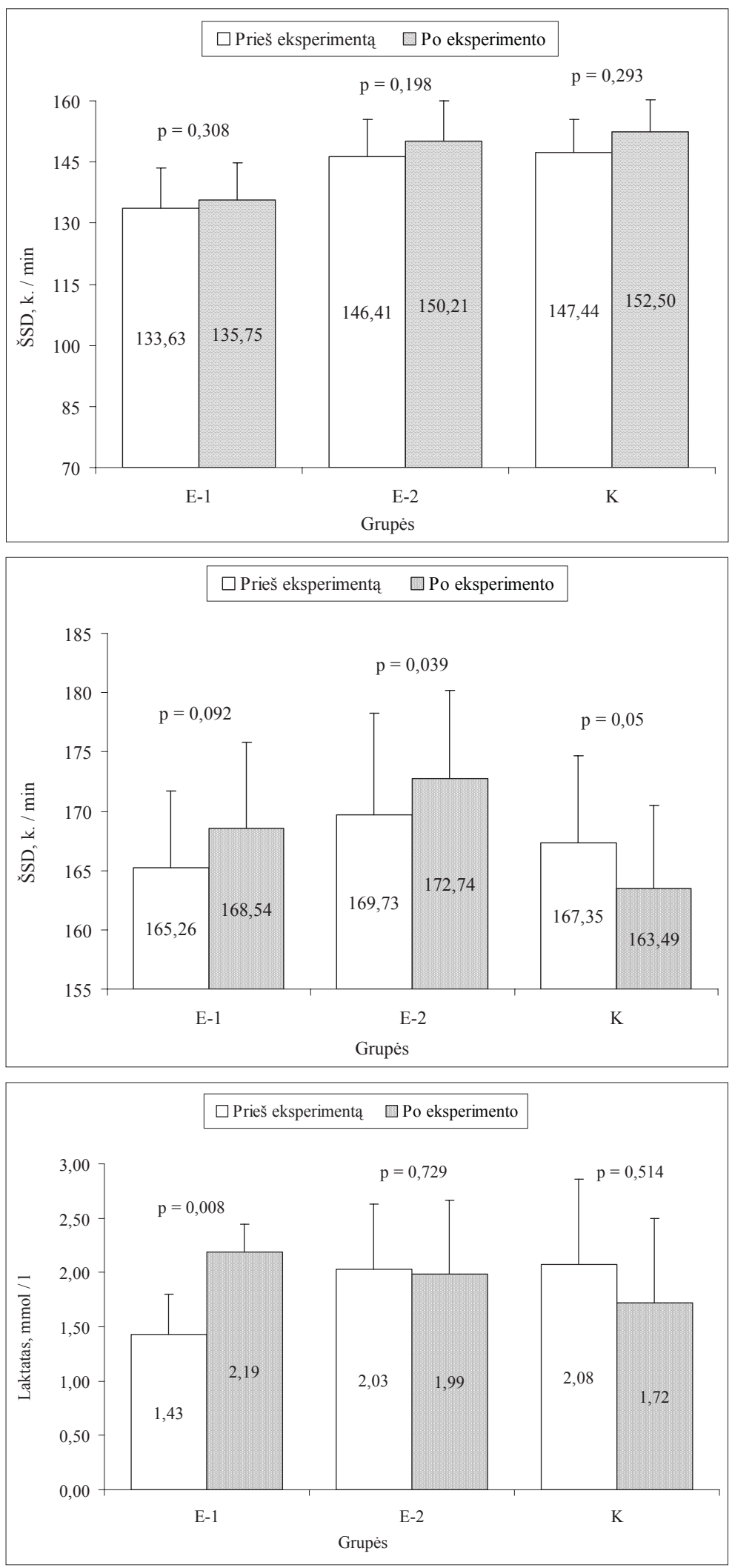

Norint padidinti anksčiau nesportavusių asmenų La ar Ve slenksčiu rodiklius, pakanka pratybų metu taikyti fizinį krūvị, kurio intensyvumas neviršija LaS. Norint padidinti minètus didelio meistriškumo ištvermę lavinančių sportininkų pajègumo rodiklius, reikia taikyti didesnio nei LaS intensyvumo fizini krūvị (Londeree, 1997). Po 40 


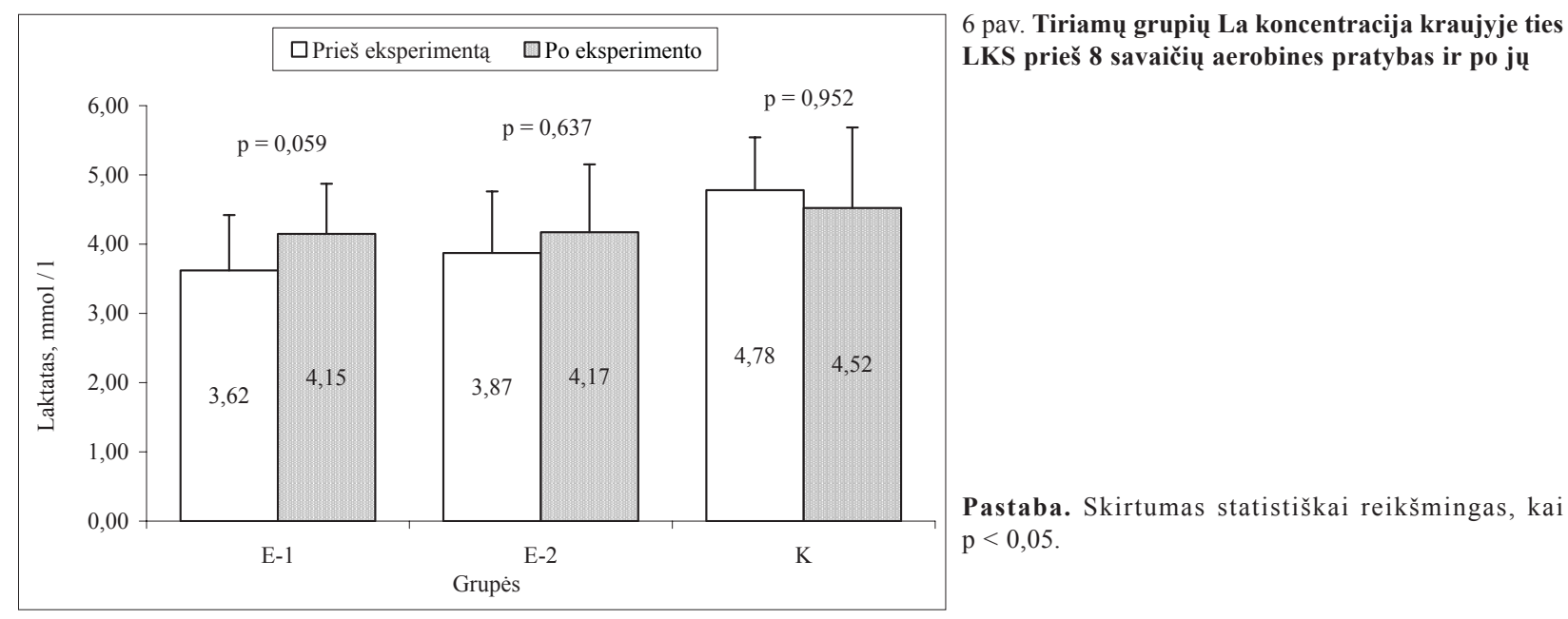

savaičių valandos trukmės veloergometro pedalų sukimo 3 kartus per savaitę, kai krūvio intensyvumas $80-85 \% \dot{\mathrm{VO}}_{2 \max }$, atitinkamai reikšmingai padidèjo VeS (10\%), LS (15\%) ir 4 mmol slenkstis $(18 \%)$. Po devynių savaičių dviračio pedalu sukimo (4 kartus po 45 min per sav.) netreniruotu vidutinio amžiaus vyrų absoliutus LaS reikšmingai padidejo 44\% (Davis et al., 1979). Mūsų tiriamuju LaS E-2 (60 min) grupèje reikšmingai padidejo $12,8 \%$, LKS $-37 \%$, E-1 (40 min) grupèje LaS padidèjo $11,7 \%$, LKS padidèjo $23,28 \%$. Abieju grupių vyrų, kurie treniravosi 2 mènesius 4 kartus per savaitę po 30 minučių mažu $\left(53 \% \dot{\mathrm{VO}}_{2 \max }\right.$ arba $72 \% \mathrm{LaS})$ ir dideliu $\left(82 \% \dot{\mathrm{VO}}_{2 \max }\right.$ arba $\left.121 \% \mathrm{LaS}\right)$ intensyvumu, LaS padidejo reikšmingai $10-12 \%$; $\mathrm{p}<0,01)$ (Belmen, Gaesser, 1991). Šio tyrimo autoriai nustatè panašu LaS padidèjimą kaip ir mes (apie 12\%). H. P. Golden ir P. Vaccaro (1984), ištyrę 18 nesportuojančių studentų, kurie aštuonias savaites po 30 minučiu suko dviračio pedalus skirtingu intensyvumu ( $\mathrm{LaS}$, tarp $\mathrm{LaS}$ ir $\left.\mathrm{VO}_{2 \max }\right)$, nustaté, kad nè vienos grupès tiriamuju pratybos LaS rodiklių reikšmingai nepakeitè. Šio tyrimo rezultatai neprieštarauja mūsų gautiesiems - 40 minučių pratybų trukmé LaS intensyvumu buvo per trumpa, kad statistiškai reikšmingai padidintu AAS. Neseniai nustatyta, kad 45 minučių trukmès pratybos labiau negu 30 minučiu reguliarios pratybos padidina vyresnio amžiaus moterų $\dot{\mathrm{V}}_{2 \max }$ esant tam pačiam pratybu intensyvumui (50\% $\dot{\mathrm{V}} \mathrm{O}_{2 \max }$ ) (Dalleck et al., 2009). Poveikio AAS minètieji autoriai netyrè.

Manoma, kad AAS labiausiai susiję su dirbančiu raumenų aerobinio metabolizmo ypatumais (Jacobs, 1981; Foxdal et al., 1994). Buvo teigta, kad tiek oksidacinès galimybès, tiek tiriamuju raumenu kompozicija yra susijusi su metaboliniu intensyvumu, kurị apibrěžia AAS (Ivy et al., 1980).
Padidèjusių AAS po ištvermės pratybų priežastis gali būti pagerèjęs treniruotų raumenų kraujo pasiskirstymas, didesnès jų aerobinès oksidacijos galimybès ir pokyčiai skaidulų rekrutavimo modelyje didinamo krūvio metu dèl padidèjusios lètuju oksidacinių skaidulų aktyvacijos. Autorių teigimu, padidejęs AAS įrodo raumenų oksidacinio galingumo pokyčius dèl ištvermès pratybu poveikio (Denis et al., 1982). Dèl treniruočiu mitochondrijų kiekis raumenyse gali padideti $50-100 \%$ (Holloszy, Coyle, 1984). Toks mitochondrijų tūris padidina aerobinès energijos tiekimo pajègumą dèl pagreitejjusios riebalų rūgščiu ir angliavandenių oksidacijos (Mole et al., 1971), todèl mažiau susidaro laktato (Holloszy, Coyle, 1984). Be to, irodyta, kad ištvermès pratybos padidina laktato šalinimą (Donovan, Brooks, 1983) ir sumažina jo produkciją (Favier et al., 1986) dirbant tuo pačiu intensyvumu.

Ko gero, ilgesnès pratybos labiau padidina raumenų mitochondrijų kiekị. Tai gali būti susiję su didesnio raumenu skaidulų kiekio dalyvavimu veikloje kompensuojant nuovargi, todèl adaptacija apima didesnę raumens dali, ir bendri mitochondrijų pokyčiai yra didesni. G. Dudley ir kt. (1985), atlikdami eksperimentą su žiurkèmis, nustatė: nors didžiausią poveiki mitochondrijų pokyčiams turi ištvermès pratybų intensyvumas, ilgesnè trukmé taip pat sukelia didesnius mitochondrijų pokyčius, jei pratybu intensyvumas viršija $50 \% \dot{\mathrm{VO}}_{2 \max }$.

\section{IŠVADA}

Tik 60 minučių trukmès aerobinès pratybos, atliekamos du mėnesius triskart per savaitę laktato slenksčio intensyvumu, reikšmingai padidino merginu AAS, kai tuo tarpu 40 minučiu pratybos reikšmingo poveikio neturejjo. 


\section{LITERATŪRA}

American College of Sports Medicine. (2006). ACSM's Guidelines for Exercise Testing and Prescription. Lippincott: Williams \& Wilkins.

Belman, M. J., Gaesser, G. A. (1991). Exercise training below and above the lactate threshold in the elderly. Medicine and Science of Sports and Exercise, 23 (5), $562-568$.

Cabrera, M., Chizeck, H. (1996). On the existence of lactate treshold during incremental exercise: A systems analysis. Journal of Applied Physiology, 80 (5), 1819-1828.

Dalleck, L. C., Allen, B. A., Hanson, B. A. et al. (2009). Dose-response relationship between moderate-intensity exercise duration and coronary heart disease risk factors in postmenopausal women. Journal of Womens Health (Larchmt), J18 (1), 105-113.

Davis, J. A., Frank, M. H., Whipp, B. J., Wasserman, K. (1979). Anaerobic treshold alterations caused by endurance training in middle-aged men. Journal of Applied Physiology, 46 (6), 1039-1046.

Denis, C., Fouquet, R., Poty, P., Geyssant, A., Lacour, J. R. (1982). Effect of 40 weeks of endurance training on the anaerobic threshold. Journal of Sports Medicine, 3 (4), $208-214$

Donovan, C. M., Brooks, G. A. (1983). Endurance training affects lactate clearance, not lactate production. American Journal of Physiology, 244 (1), E 83-92.

Dudley, G., Abraham, W., Terjung, R. (1985). Influence of exercise intensity and duration on biochemical adaptations in skeletal muscle. Journal of Applied Physiology, 53, 844-850.

Favier, R. J., Constable, S. H., Chen, M., Holloszy, J. O. (1986). Endurance exercise training reduces lactate production. Journal of Applied Physiology, 61 (3), 885-889.

Foxdal, P., Sjödin, B., Sjödin, A., Ostman, B. (1994). The validity and accuracy of blood lactate measurements for prediction of maximal endurance running capacity. Dependency of analyzed blood media in combination with different designs of the exercise test. Journal of Sports Medicine, 15 (2), 89-95.

Golden, H. P, Vaccaro, P. (1984). The effects of endurance training intensity on the anaerobic threshold. Journal of Sports Medicine and Physical Fitness, 24 (3), 205-211.

Holloszy, J. O., Coyle, E. F. (1984). Adaptations of skeletal muscle to endurance exercise and their metabolic consequences. Journal of Applied Physiology, 56, 831-838.

Ivy, J. L., Withers, R. T., Van Handel, P. J., Elger, D. H., Costill, D. L. (1980). Muscle respiratory capacity and fiber type as determinants of the lactate threshold. Journal of Applied Physiology, 48 (3), 523-527.
Jacobs, I. (1981). Lactate concentrations after short, maximal exercise at various glycogen levels. Acta Physiologica Scandinavica, 111 (4), 465-469.

Kesaniemi, Y. K., Danforth, E., Jensen, M. D. et al. (2001). Dose-response issues concerning physical activity and health: an evidence-based symposium. Medicine and Science of Sports and Exercise, 33 (6), S 351-358.

Kulis, Y. Y., Laurinavichyus, V. S. A., Firantas, S. G. A., Kurtinaitienè, B. S. (1988). Determination of lactic acid with and Exan-G analyser. USSR Journal of Applied Chemistry, 43 (7), 1521-1523.

Londeree, B. R. (1997). Effect of training on lactate / ventilatory thresholds: A meta-analysis. Medicine \& Science in Sport \& Exercise, 29 (6), 837-843.

McNicol, A. J., O’Brien, B. J., Paton, L. D., Knez, W. L. (2009). The effects of increased absolute training intensity on adaptations to endurance exercise training. Journal of Science and Medicine in Sport, 12 (4), 485-489.

Meyer, T., Auracher, M., Heeg, K., Urhausen, A., Kindermann, W. (2007). Effectiveness of low-intensity endurance training. Journal of Sports Medicine, 28 (1), 33-39.

Mole, P. A., Oscai, L. B., Holloszy, J. O. (1971). Adaptation of muscle to exercise. Increase in levels of palmityl Co-a synthetase, carnitine palmityltransferase, and palmityl Vo-a dehydrogenase, and in the capacity to oxidize fatty acids. Journal of Clinical Investigations, 50, $2323-2330$.

Pollock, M. L., Wenger, N. K. (1998). Physical activity and exercise training in the elderly: A position paper from the society of geriatric cardiology. American Journal of Geriatric Cardiology, 7 (4), 45-46.

Skinner, J. S., McLellan, T. H. (1980). The transition from aerobic to anaerobic metabolism. Research Quarterly for Exercise and Sport, 51, 234-248.

Stasiulis, A., Ančlauskas, R., Jaščanin, J. (2000). The effects of training intensity on blood lactate breakpoints in runners. Journal of Human Kinetics, 3, 17-26.

Tanaka, K. (1990). Lactate-related factors as a critical determinant of endurance. Annals of Physiology, Antropology, 9 (2), 191-202.

Wasserman, K., Whipp, B. J., Koyal, S. N. et al. (1973). Anaerobic threshold and respiratory gas exchange during exercise. Journal of Applied Physiology, 35, 236-243.

Weltman, A. (1995). The Blood Lactate Response to Exercise. Champaign, IL: Human Kinetics. P. 117. 


\title{
INFLUENCE OF TWO MONTHS OF REGULAR AEROBIC EXERCISE OF DIFFERENT DURATION ON ANAEROBIC THRESHOLDS IN YOUNG WOMEN
}

\author{
Asta Mockiené ${ }^{1,2}$, Arvydas Stasiulis ${ }^{1}$, Pranas Mockus ${ }^{1}$ \\ Lithuanian Academy of Physical Education ${ }^{1}$, Vytautas Magnus University ${ }^{2}$, Kaunas, Lithuania
}

\begin{abstract}
The aim of the study was to compare the influence of aerobic cycling sessions with lactate threshold (LT) intensity but different (40 and $60 \mathrm{~min}$ ) duration.

34 healthy, untrained, non smoking young women volunteered to participate in the study. They were divided into three groups: two experimental E-1 $(\mathrm{n}=9$; age $-24 \pm 1.4$ years, height $-1.71 \pm 0.88 \mathrm{~m}$, body mass $-68.3 \pm 7.4 \mathrm{~kg}), \mathrm{E}-2(\mathrm{n}=15$; age $-23.5 \pm 1.2$ years, height $-1.70 \pm 0.52 \mathrm{~m}$, body mass $66.3 \pm 8.6 \mathrm{~kg})$ and control $\mathrm{C}(\mathrm{n}=10$, age $-22.7 \pm 1.3$ years, height $-1.69 \pm 0.44 \mathrm{~m}$, body mass $65.8 \pm 8.9 \mathrm{~kg}$ ). Eight weeks participants of E-1 ir E-2 groups performed regular (three times per week) cycling exercises with LT intensity but different duration (E-1 - $40 \mathrm{~min}, \mathrm{E}-2-60 \mathrm{~min}$ ). The participants of $\mathrm{C}$ group did not exercise during this period of time.

The LT and lactate accumulation threshold (LAT) were estimated according to the relationship between blood lactate concentration and intensity during intermittent increasing cycling exercise. Both thresholds were identified by means of linear regression analysis. All the groups were tested twice: before and after 8 weeks of experimental period.

The results showed that there were no significant changes of anaerobic thresholds and other related parameters in group E-1 that used 40 min duration of exercise sessions. In group E-2 that performed exercise sessions of 60 min duration the significant increases of LT $(p=0.021)$, LAT $(p=0.013)$ and HR at LAT $(\mathrm{p}=0.039)$ were observed. No significant changes were detected in control group.

It is concluded that only $60 \mathrm{~min}$ duration of exercise sessions can increase significantly anaerobic threshods in young untrained women exercising three times a week at the intensity of LT.
\end{abstract}

Keywords: lactate, anaerobic thresholds, duration of aerobic exercise sessions, cycling ergometry.

Gauta 2009 m. gegužès 6 d.

Received on May 6, 2009

\author{
Asta Mockienè \\ Vytauto Didžiojo universitetas \\ (University Vytautas Magnus) \\ Draugystès g. 19, LT-44001 Kaunas \\ Lietuva (Lithuania) \\ Tel +37064872515 \\ E-mail a.mockiene@spc.vdu.lt
}

